\title{
Protumodernost modernoga - pjesnički protusvijet Julija Benešića
}

\begin{abstract}
Rogić Musa Tea, Protumodernost modernoga - pjesnički protusvijet Julija Benešića (Counter-Modernism of the Modern - the Poetical Counter-World of Julije Benešić). "Poznańskie Studia Slawistyczne" 17. Poznań 2019. Publishing House of the Poznań Society for the Advancement of the Arts and Sciences, Adam Mickiewicz University, pp. 221-235. ISSN 2084-3011.
\end{abstract}

This article deals with the poetry of Julije Benešić (his collection Istrgnuti listovi - Torn Pages) in the context of Croatian modernist poetry based on three assumptions: the first, deductive one is that Benešić's literary, literary-historical, theatrical and public personality is a potential metonymy of the entire Croatian culture of the first two decades of the $20^{\text {th }}$ century; the second, literary-historical assumption is that the choice to use free verse can be read as a counter-modernist gesture against rationalism and structure of rhymed verse of Croatian modernist poetry; third, from the culturalhistorical point of view, it is assumed that Benešićs poetical profile is a reflection of his countermodernist attitude that was shaped beyond the dominant poetical practices of modernism. The goal of this presentation is as much a cultural-historical as it is a literary-historical one, aimed at proving a thesis by which a small poetical contribution by Julije Benešic is synecdoche for the condition and the atmosphere of Croatian culture of the late modernism and the first interwar years. The notion of counter-modernism is historiographically restricted here and encompasses Benešić's disputing statements in relation with the dominant paradigm in synchrony with the modernist period. The choice of free verse is understood as a statement of notion about the restraints of the poetics of rhymed verse of Croatian modernism. Since free verse was not part of the canon at the time, Benešić tried to use it to legitimize his own work and democratize the system of poetical competencies.

KeYwords: Julije Benešić; free verse; Croatian modernism

\section{Julije Benešić u sastavu teme o umjetnosti i demokraciji}

Čitajući studiju, zapravo niz pojedinačnih eseja, The Western Canon Harolda Blooma (1994) i istodobno čitajući nekog hrvatskoga književnika, nemoguće je ne promisliti o proizvoljnosti književnoga kanona, osobito kad je riječ o književnosti XX. st. Odveć je poznato koliko se književna znanost tijekom druge polovice XX. st., neuspjelo, hrvala s mogućnostima 
preispitivanja starih načela definiranja kanona, ne uspijevajući pritom ni iz svoje suvremenosti probrati reprezentativan niz književnih djela koja bi nam danas svima, i nama s neengleskoga područja, pod uvjetom da prihvaćamo zapadni kanon kao vlastiti obzor, bila vodič i kriterij. Ne treba tumačiti kako u takvoj proizvoljnosti prolaze književnosti malih naroda i malih jezika. Poznato je, u Bloomovoj podjeli, koja zanemaruje „periferije“ europske kulture (navedimo da je u njegovim popisima djela koja pripadaju kanonu najmanje slavenskih autora), razdoblje XIX. st. i djelomično prijelaz u XX. st. pripada tzv. demokratskom dobu. Razdoblje koje slijedi, i još traje, tzv. je kaotično doba ${ }^{1}$. Razmišljajući u hrvatskim okvirima, tri su pretpostavke bitne: prvo je razdoblje hrvatske neupitne usklađenosti i sinkroniziranosti s europskom paradigmom bila moderna; po svojim kulturnim, društvenopolitičkim i ideološkim značajkama moderna je tipsko razdoblje na razmeđu demokratskoga i kaotičnoga doba (šteta što je Bloom nedovoljno prepoznao srednjoeuropski modernizam i uopće europski fin de siècle kao zoran primjer previranja između dviju paradigmi). Naša usmjerenost na razdoblje moderne i istraživačka, kadšto vrlo privatna i osobnočitateljska usmjerenost na ključnu ličnost hrvatsko-poljskih tema, riječju na Julija Benešića, vodi pitanju je li Benešić, nesumnjivi velikan hrvatske kulture, dovoljno markantan poetski i uopće književni autor da ga se kontekstualizira s obzirom na kanon hrvatske moderne i, šire, kanon srednjoeuropskoga modernizma, u koji, neovisno o svojoj samobitnosti i nizu specifičnosti povezanih s poljskom književnom tradicijom XIX. st., pripada paradigma Mlade Poljske prema kojoj se, uvjereni smo, Benešić kao pjesnik oblikovao.

Ne ohrabruje činjenica da Julije Benešić nije dosad, naglasimo kao pjesnik, bio književnopovijesno povezan s vrhovima hrvatskoga kanona toga razdoblja, naime s Antunom Gustavom Matošem i (mladim) Miroslavom Krležom. To je krak koji valja slijediti jer Benešićeve veze s dvojicom književnika ne smiju se u ovom slučaju svoditi na osobne kontakte i književni život, što se s Benešićem interpretacijski uvijek događalo, zbog očite njegove uključenosti u razne životne okolnosti dvojice književnih

${ }^{1}$ Kriterije podjele i načelna opažanja o kanonu, izvedena dakako iz pojmovlja angloameričke književnokritičke tradicije, Bloom tumači u poglavlju An Elegy for the Canon (Bloom, 1994, 15-41). 
velikana. Vlastite razloge za takva književnopovijesna preispitivanja moramo okarakterizirati kao postupak ad libitum, kao blumovski, proizvoljno odabran uzorak za koji vjerujemo da je reprezentativan za prijelaz između „demokratskoga“ i „kaotičnoga“ doba. Bez previše premišljanja, iako će o tom još dakako biti govora, smještamo Benešića u demokratsko doba, u epohu raniju u odnosu na njegovo javno djelovanje. Kao književni autor, Benešić ne pripada međuraću nego moderni, i to ne onoj s kraja, nakon Matoševe smrti, nego moderni s prijelaza stoljeća. Kao autor ,demokratskoga" doba bira slobodni stih, koji tada još ne pripada hrvatskom kanonu (iako je drugdje već bio kanoniziran), i smješta ga u kontekst poetskoga impresionizma, vrativši se tako poetički, naoko, korak unatrag. Ta ambivalentnost Benešićeva, upotreba najmodernijega postupka unutar poetike koja je neoromantička (jer crpi svoje nadahnuće iz kanona XIX. st.), poziva na promišljanje $\mathrm{u}$ čemu se sastoji zaokret $\mathrm{u}$ lirskoj modernosti što su ga donijele poetike moderne i zašto je protumodernost znamen upravo srednjoeuropske moderne i unutar nje poetskoga impresionizma. Poetski profil Julija Benešića sadržava sukus toga dvostrukoga zaokreta - odbijanje versifikacijskoga kanona moderne s jedne strane i duhovno utjecanje romantizmu, impresionizmu i svjetonazorskom konzervativizmu s druge strane. Zagledavši se u opus, a maknuvši barem donekle fokus s biografije i javne osobe, ta se podvojenost ne doima paradoksalnom nego razumljivom. Uvidi koji slijede pokušat će objasniti u čemu se sastoji izazov književnopovijesnoga tumačenja Julija Benešića i zacrtati put prema možebitnim rješenjima na tragu temeljnoga preduvjerenja da se modernu, imajući $\mathrm{u}$ vidu naslovnu temu Umjetnost $i$ demokracija, ne bi smjelo zaobići jer je posljednja etapa tzv. demokratskoga doba. U takvu ključu Julije Benešić mogao bi biti uvjerljivo, pa i vjerodostojno, „lice s granice“ (unutar metafore slavenske uzajamnosti), čovjek dviju kultura, autor dvaju jezika, privržen domaćemu, zagledan u strano, i moderan i staromodan, riječju „studija primjera“ ambivalentne modernosti hrvatske moderne.

\section{Uvodno razmatranje: književnopovijesni kontekst}

Zamišljen kao komparativno-književnopovijesna prolegomena u sveobuhvatno čitanje i tumačenje književnoga djela Julija Benešića, ovaj rad 
zahtijeva na svojem početku nekoliko načelnih opaski dijakronijske naravi. Julije Benešić jedan je u mnoštvu tzv. malih autora tzv. male hrvatske književnosti. Većina suvremenih tumača književnosti ne priznaje mogućnost podjele na male i velike književnosti, male i velike pisce, no lišimo li se svakoga licemjerja, priznat ćemo da se nerijetko upravo hrvatskoj književnoj historiografiji zamjerao fokus na neznatne autore slaba recepcijskoga učinka, koji nemaju druge vrijednosti doli dokumentarne, i to usko unutar okvira nacionalne književnosti ${ }^{2}$. U povijestima hrvatske književnosti i u metajeziku književne kritike, osobito prve polovice XX. stoljeća, nisu rijetke takve, nazovimo nekorektne odrednice, koje zacijelo autora poput Julija Benešića smještaju na marginu književne dijakronije, osobito iz vizure kanona svjetske književnosti ${ }^{3}$. Od te vizure bježati se ne smije, koliko god se činila nepotrebnom kad je riječ o razmjerno neocijenjenom autoru u našoj književnoj historiografiji, kakav je Benešić ostao, imajući na umu samo njegovo književno djelo ${ }^{4}$. Nije ovdje riječ o pokušaju njegova kanoniziranja nego o pokušaju potpunijega književnopovijesnoga pa i kulturnopovijesnoga pozicioniranja, no pokušat ćemo odgovoriti na pitanje je li Julije Benešić dio hrvatskoga nacionalnoga književnoga kanona. U sadašnjem kanonskom rasporedu nije zamjetno prisutan. Suprotan zaključak ne dopušta njegova recepcijska sudbina. Iako priznat u nacionalnoj filologiji kao književni pregalac, uvid u literaturu o njegovu djelu posvjedočuje da je u kritici i književnoznanstvenoj recepciji tek sporadično prepoznat kao (interpretacijska) tema. U hrvatskoj književnosti mogućnost kanonizacije, taman nestabilna i proizvoljna, kao da je postala uvjet književnoznanstvenoga tematiziranja. U takvu ključu Benešić naprosto nije još došao na red (priznatost u nacionalnoj filologiji i priznavanje zasluga za pregalaštvo nisu put u književni kanon). Našu nakanu, koja se nameće iz naslova, ne

${ }^{2}$ Paradigmatski je primjer takva uvida, kojemu se ne može osporiti golema književnopovijesna korist, studija Antuna Barca Veličina malenih (Zagreb, 1947). U novije doba utjecajan je pogled Viktora Žmegača na tu temu (Žmegač, 1997, 273-282).

${ }^{3}$ Iako proizašao iz kurikula američkih sveučilišta, u pristupu pojmu kanona oslonili smo se na već spomenut uvid H. Blooma, koji je popisao kanonska djela tzv. demokratskoga doba (Bloom, 1994, 541-548).

${ }^{4}$ Nemajući prostora za analizu impresionizma u zbirci Istrgnuti listovi, napomenimo da poticajne uvide u tu temu nude Pavao Pavličić u poglavlju Julije Benešić kao pjesnik (u knj. Barokni pakao, Pavličić, 2003, 297-300) i Hrvoje Pejaković u pogovoru Julije Benešić u izdanju Izabrani tekstovi (Pejaković, 1994, 137-149). 
treba tumačiti kao pokušaj da se Benešića kao književnoga autora, služeći se kategorijama umjetnih svjetova ili protusvjetova, promovira u nekovrsni antikanon. Njegov je doprinos nastao onkraj kanona, pa se tako Benešića ne može valjano čitati i tumačiti ako se zanemare Matošs i Krleža, vrhovi hrvatskoga kanona te, ne manje bitno, njegova zauzetost poljskim kanonom, čijim je čitanjem i prevođenjem uspostavljao kriterije presudne i za vlastita stajališta o matičnoj književnosti te o svojoj ulozi u njoj.

Nadalje, pođimo od postavke da je Benešić metonimija uzajamnosti kulturnih procesa u poljskoj i hrvatskoj sredini u prvim desetljećima XX. stoljeća. Nemajući ovdje prostora detaljnije komentirati tadašnje poljske okolnosti, podsjetimo tek da je upravo poljska situacija kroz XIX. stoljeće do I. svjetskoga rata dokaz da se državnopolitički utjecaj neke zajednice ne mora podudarati s njezinom kulturnom važnošću jer odjeke i utjecaje poljske književnosti toga doba ne prati i politička moć. Toga raskoraka Benešić je bio svjestan još iz svoje mladosti ${ }^{6}$. Kako bismo izbjegli lakoću naoko evidentna Benešićeva povođenja za poljskom književnošću i da se načas vratimo na nepriznatu, ali žilavu podjelu na male i velike književnosti, podcrtajmo da je poljska književnost upravo u doba Benešićeve mladosti bila velika slavenska književnost, za vanjskoga promatrača i štovatelja (naročito iz južnoslavenskih krajeva) veća nego ikad prije - oslonjena na još uvijek živu tradiciju u svjetskim razmjerima golema odjeka romantizma, s nizom velikih autora i romana na prijelazu stoljeća, istodobno otvorena novim poetikama u pjesništvu, te postaje temelj Benešićeve umjetničke misaonosti ${ }^{7}$. Taj je temelj u gotovo neokrnjenu obliku prisutan u svemu što

${ }^{5}$ Podsjetimo na sentimentalan moment, naime da je Benešić govorio u ime DHK na Matoševu sprovodu: „Dragi nemirni duše, dovršila se tvoja pečalba, tko će tvoje mjesto zauzeti i ima li tvojem temperamentu premca? Tko će porazbacati iverje tvoga duha po Hrvatskoj; svezan uz male stijene hrvatske, grlato si branio hrvatsko gnijezdo; lupao si krilima o žice našeg tijesnog kaveza; tvoj dom je na dogledu dragih iliraca. Sada si naš kao uspomena koju ne briše vrijeme“" (Benešić, 1943, 99-100).

${ }^{6}$ Spomenimo da je prvi tekst koji je Benešić objavio (1901), kako ga naziva, „monolog“ naslova Godina 1795., u đačkom listu Nova zviezda, otisnut s krivim naslovom (Godina 1789) jer je urednik mislio da se naslov odnosi na Francusku revoluciju, a ne na treću diobu Poljske. Ohrabren, neke je prozne sastavke slao i u druge časopise, no nisu izašli pa je zarana odustao od pisanja proze.

${ }^{7} \mathrm{O}$ tome sam svjedoči u jednom od ključnih eseja svojeg opusa - Nacionalizam i patriotizam u književnosti (Benešić, 1943, 87-93). 
je Benešić činio i pisao. Nema, dakako, poljska književnost u Benešićevu opusu apsolutnu vrijednost, uloga joj je kadšto operativna, mjestimično i didaktičko-heuristička, ali u središtu Benešićeve „kronologijske karte književnoga zemljopisa" ${ }^{\text {"8 }}$ - u Autobiografiji, objavljenoj u knjizi Kritike $i$ članci, napisao je:

Mnogo sam vremena proživio u Poljskoj. Netko mi u nekoj zdravici reče, da mi je to druga domovina. Smiješno! Kao da je to moguće. Domovina može biti samo jedna, ili nijedna, kao kod Cigana, koji je nemaju. Bilo je doduše i takvih tipova kod nas, kojima je domovina bila čitava Austrougarska, no ti su sada ili već u grobu ili u naftalinu. Mi imamo divnu rieč: zavičaj. [...] Kako možemo imati samo jedan svoj rodni dom, tako nam može biti samo jedna domovina (Benešić, 1943, 294).

\section{Benešić u sastavu hrvatske moderne}

Mijene u zapadnoeuropskim književnim središtima koje potječu još iz 1880-ih (u Francuskoj dakako i ranije) kao što su postale modelski primjenjive u poljskoj sredini, čega mladi Benešić zacijelo postaje svjestan za studija u Krakovu, postaju znamen razdoblja i u hrvatskoj književnosti moderne. Dio je toga znamena i slobodni stih. ${ }^{9}$ U eseju Rieč $i$ ljepota u književnosti (Hrvatski pokret, 1913) najjasnije svjedoči o svojem impresionističkom nagnuću:

Čitajući pjesničko djelo ne ćemo se hvatati rieči, već ćemo tražiti dojam, nastojati shvatiti misao. Dakako, i dojam se izaziva u književnosti riečima i misao se njima izriče, ali pitanje je ovdje nabačeno, da li ćemo moći u djelu uživati kako valja, ako ne razumijemo svaku rieč autorovu (Benešić, 1943, 94).

Sažimajući taj esej, evidentno je da Benešić sudi na temelju čitateljskoga iskustva strane književnosti: „Ne ćemo smjeti čitati djela u stranom jeziku jer, priznajmo, nema među nama čovjeka, koji bi bilo kojim stranim jezikom tako govorio, da razumije svaku rieč toga jezika“ (Benešić, 1943, 95). Pita se: ako nismo razumjeli baš svaku riječ, znači li to da nismo razumjeli smisao djela? Benešić piše ovaj esej kao prevoditelj, ali i kao

\footnotetext{
${ }^{8}$ Viktor Žmegač se služi takvim opisom govoreći o kriteriju starosti pri književnopovijesnom situiranju europskih književnosti (Žmegač, 1997, 278).

${ }^{9}$ U teoriji slobodnoga stiha služimo se analizom Slavena Jurića (Jurić, 2005, 3-30).
} 
književni kritičar (treba li kritik poznavati sve što je prethodno o djelu rečeno da bi sam bilo što spoznao?). I evo pritajena autobiografskoga momenta: „Neki pisci, individualiste, stoje u tijesnoj vezi sa svojim stvaralačkim radom, neki su opet posve nezavisni od njega u svom curriculum vitae“ (Benešić, 1943, 97-98). Ako se diskretno sažmu, te su misli prvorazredan književni program. Sažeto, tvrdi i sljedeće „Neki velikani ne napisaše ni rieči, mada su najjače djelovali na književnosti i na razvoj duha ljudskoga, a drugi jedva da ostaviše po koji redak“ (Benešić, 1943, 97); pa ipak njihove ličnosti u književnosti vrijede nekad više od onih od kojih ostaše silni memoari; mnogi je pjesnik pisao o ljubavi i pisao je dobro, a da ljubavi nije doživio; mnogi su pisali putopise iz četiri zida, bolje od onih koji su putovali i istraživali; sve je to tako jer je „fantazija“ najjače sredstvo umjetničkoga stvaranja, važnija od bilo koje pojedinosti iz pjesnikova života; fantazija je odraz pjesnikova duha; pustimo literaturi da uđe u naša srca direktno, nesmetano, ne moramo znati sve o pjesniku da bismo razumjeli njegovu poetsku misao (Benešić, 1943, 97; esej Rieč i ljepota u književnosti).

Benešić u sastavu moderne pjesnik je jednoga od njezinih ogranaka, u terminima Zorana Kravara (Kravar, 2001, 89-96) spada u neoromantiku ili u esteticizam. Kako se i naslućuje iz tih termina, posrijedi je krak moderne koji se nije manifestativno uključivao u aktualni književni život (nemojmo pomiješati prisutnost Benešićeve javne osobe s njegovim književnim očitovanjima - on se nije izravno programatski očitovao o svojoj poetici) već se utječe romantizmu kao točki referencije ili se nadovezuje na širok pojam estetskoga. Neknjiževna stajališta podudaraju mu se s onima A. G. Matoša (ne zaboravimo da je Benešić uredio Matoševu Pečalbu u izdanju DHK), no za razliku od Matoša, kod Benešića je teže rekonstruirati političko preduvjerenje (iako je sigurno konzervativno i u pogledu hrvatskog pitanja suverenističko). Za razliku od Matoša, koji se nadahnuo na francuskom izvoru, Benešić se nadahnuo na poljskome, pa je njegova modernistička egzistencijalna i emocionalna nelagoda prepoznatljiva u antimodernizmu mladopoljskoga svjetonazora (Brzozowski, 1910, 1-23). 


\section{Pojam poetskoga protusvijeta ${ }^{10}$}

Tvrdeći da je pjesništvo Julija Benešića jedan u nizu esteticističkih protusvjetova kakvi su nastajali tijekom moderne mislimo na sasvim konkretne simbole kojima se kao pjesnik služio, a koji ne pripadaju zbilji njegova vremena. Prošlost i narodni duh i napose potraga za znakovima prošlosti u sadašnjosti znakovi su koji Benešića smještaju u antimodernistički krak moderne. Iako se takav poetički odabir i u suvremenika mu, naročito onih avangardnih težnji, osjećao kao regresivan, ponajprije zbog toga što se naslanjao na romantičku baštinu, istodobno je manifestirao senzibilitet egzistencijalne nelagode posve karakterističan za umjetnički senzibilitet moderne. Pojedinosti iz Benešićeve biografije svjedoče da je u pozadini njegova protusvijeta konzervativni svjetonazor (u smislu političke konzervativnosti u hrvatskom slučaju tu je riječ o zainteresiranosti za hrvatsku državotvornost; digresivno spomenimo, u Benešićevim kritikama ima naznaka ideološkoga svrstavanja i rezoniranja kao pomoćnoga sredstva u prosudbi književnoga djela - tu je Krleža bio najprikladniji materijal pa su iskazi o njegovim djelima najviše ideološki obojeni). Više nego Krleži, Benešićev je senzibilitet srodan Matoševu - privržen je svemu što ima neoromantički predznak (iako više tematski, nikako versifikacijski), napose svemu vezanome za konkretan hrvatski prostor (od kojega čini, jednako kao i Matoš, estetski objekt). No, suprotno od Matoša, Benešićev poetski esteticizam nije ni radikalan ni inovativan (poput Matoševa), a nacionalni mu je esteticizam pak zaoštreniji nego Matošev (iako, biografski gledano, Benešić, bitno pragmatičnije od Matoša, prihvaća novosti u građanskom životu i izvrsno im se karijerno prilagođava).

U utjecajnoj studiji Književni protusvjetovi (Batušić, Kravar, Žmegač, 2001, 250-251) Benešića se spominje usputno, kao stroga versološkoga

\footnotetext{
${ }^{10}$ Pojam protusvijeta izložio je Zoran Kravar u kontekstu hrvatske moderne u poglavlju Znaci vremena u hrvatskoj književnosti 1920-1930 u knj. Svjetonazorski separei (2005, 83-97), a teorijski najpotpunije u studiji Antimodernizam (2003), u užem smislu kao naziv za poetičku ili svjetonazorsku antimodernost unutar paradigme moderne. Antimodernost ili, ublaženo, protumodernost u pojedinačnih autora sinegdoha je njihova poetičkoga (nerijetko i političkoga) stava koji sadržava elemente negacije moderne. Za Benešića je upravo karakteristično da njegova protumoderna očitovanja ne posjeduju uporište izvan moderne, pa ne mogu biti zamijenjena za predmoderne tendencije niti za protoavangardna osporavanja moderne.
} 
ocjenitelja stihova Frana Galovića u njegovim jednočinkama (što je objavljeno u komentarima uz Galovićeva Sabrana djela). Kao pjesnik nije bio tema iz razloga povezanih s kanonom moderne, ali nedvojbeno se opća mjesta lirike moderne mogu uočiti i u zbirci Istrgnuti listovi. Očita je dvojnost njegova poetskoga postupka: iako nastoji unijeti u pjesme znakove civilizacije (grad, svakodnevica, društvene situacije), njegov je poetski svijet umjetan, konstruiran. Posebnost je hrvatskoga društvenoga konteksta u kojem je Benešić djelovao to što je tadašnja književnost znatno modernija od društva u kojem je nastajala. Paradoks Benešićeva slučaja sastoji se u sljedećem: unutar poetskoga svijeta gradio je sliku života koja se podudara sa znakovima građanske kulture moderne, a istodobno odbijao „modernost" moderne jer ju je vidio kao znak vanjskih utjecaja (koje je, pod teretom društvenih okolnosti, tumačio kao tuđinske).

Esej o Krležinoj Podnevnoj simfoniji (O hrvatskom ritmu; Benešić, 1917, 35-39) povod je Benešiću za načelna opažanja, koja razotkrivaju i njegovu poetiku. Jedini u tadašnjoj kritici pobliže komentira novost u stihotvorstvu (kako je dobro poznato, prvi su slobodni stihovi u nas oni Vladimira Jelovšeka, Simfonije, 1898, 1900, potom u Psovci Janka Polića Kamova 1907. i većina pjesama Ive Andrića u Hrvatskoj mladoj lirici 1914., no u kritici je izostala diskusija o tim poetikama). Benešićev pokušaj refleksije ostao je usamljen. Kao i sva kritika nastala do 1920. (pa i kasnije), Benešić svoja zapažanja ne utemeljuje teorijski nego kritičko-impresionistički, iako s obzirom na svoja filološka znanja navodi (neprecizno) i jezične osobine hrvatskoga jezika (duljina, naglašenost) relevantne za ritam. Glavne su teze ove (a sve proizlaze iz temeljne uvjerenosti u uvjetovanost „narodne duše“ i jezika): hrvatski je jezik prirodno muzikalan; hrvatsko pjesništvo ne raspolaže versifikacijom koja bi se okoristila tom prirodnom muzikalnošću (za to optužuje napose filologe koji su prema stranim uzorima normirali hrvatski stih - Matija Petar Katančić, Adolfo Veber Tkalčević, Ivan Trnski - „među onima koji su u nas pisali o metrici ni jedan nije napisao valjanog stiha“; ,naš jezik ne valja natezati na rimske i aleksandrinske sheme“" (Benešić, 1917, 36); Krleža je iznašao stih koji afirmira tu prirodnu muzikalnost jer je kao pjesnik osjetljiv na prozodijske vrednote; oslobodio se metra i ostvario prirodnu muzikalnost. - To objašnjava zašto Benešić piše slobodnim stihom. Važnije je, međutim, da je Benešiću ideja o vezi između muzikalnosti jezika i nacionalnoga karaktera zacijelo bila 
poznata iz knjižice Przybyszewskoga Chopin i narod, kojoj je tema neodvojivost jezika, glazbe i narodne duše). Istaknuli smo već da Benešić odbija modernost moderne - evo primjera: iako afirmira slobodni stih, ne čini to iz potrebe da pohvali poetsku inovaciju i originalnost niti uopće drži do kategorije novoga, koja dominira manifestima toga doba; njegov je argument književnopovijesni, čak izravno neoromantički - hrvatski vezani stih nikad nije funkcionirao jer je sputavao nacionalni jezik koji u vezanom stihu ne može razviti svoju muzikalnost. Povijest slobodnoga stiha svjedoči da se njegova afirmacija povezivala s okretanjem pjesništva intimnosti i sa sveopćom demokratizacijom u umjetnosti (Jurić, 2003, 107-128). Usred paradigme moderne Benešić pohvaljuje Krležin nemetrički stih zbog njegova povratka ,autentičnosti nacionalnoga jezika“. Pa iako mu stihovi obiluju znakovima individualne duševnosti, kao Krležin kritičar to ne vrednuje (jer je usredotočen na „dušu naroda“). Važno je za čitanje njegovih pjesama da Benešić pojam ritma ne tumači versološki, njemu je to općenit sklad forme i sadržaja, svi eufonijski postupci koji služe isticanju ritmičkih vrlina hrvatskoga jezika.

Ako se danas kritika o Krležinu ritmu čini dokazom promašenosti Benešićeva kritičkoga aparata (kritičku potragu za formalnim odlikama naziva „ludorijama“"11; naš jezik ne treba rime, samo nas smetlari jezični zbrkaše da posumnjamo govorimo li uopće hrvatski ili je to neko „,barbarsko iverje“"12), naglasimo da je njegov pogled kulturnopovijesni, na tragu senzibiliteta kasne hrvatske moderne, pa su neka njegova stajališta iz toga eseja postala opća mjesta hrvatske kritike (,pjesnik je onaj, koji govori dobro i kad ne govori gramatički“" $)^{13}$. Nadalje, treba naglasiti i da je ličnost Julija Benešića, onako kako se otkriva u eseju o ritmu, zahvaćena pojavama o kojima sam piše. U vlastitoj upotrebi slobodnoga stiha očita je privatnost stava, pa i stanovita lakoća u izboru te neopterećenost uspjelošću toga

${ }^{11}$ „Ludorije, koje ubijaju smisao i svrhu pjesme“ (Benešić, 1917, 36).

${ }^{12}$,Ta mi svi to dobro znamo, samo nas poplašiše korenodupci, pometači i smetlari jezični, koji pronadjoše milijarde nepravilnosti u onom govoru, s kojim se dnevno služimo, i zbrkaše nas već do toga stepena, te možemo i posumnjati: govorimo li doista hrvatski, ili je to samo neko barbarsko iverje, što leti iz naših usta“" (Benešić, 1917, 37).

${ }^{13}$ „Pjesnik je onaj, koji govori dobro i onda, kad ne govori gramatički, iz njegovih usta dišu ruže, kao iz ustiju Ovidijeve Flore“ (Benešić, 1917, 37). 
izbora. Motiv je toga Benešićeva opredjeljenja utjecaj Przybyszewskoga, kojega Benešić i citira:

svaki narod ima neki posebni ton, prema kojemu je cijela njegova duša udešena; taj je ton drukčiji kod germanskih, a drugi kod romanskih naroda, no posve je različit kod slavenskih naroda. Oćutjeti specifičku vrijednost toga tajinstvenoga tona, posjedovati snagu, da se sve druge vrijednosti prilagode tom temeljnom tonu, to je snaga pojedinoga umjetnika, a ujedno je to i mjerilo, koliko je taj umjetnik narodan ili nije (Benešić, 1917, 38).

Benešić je i prevodio Przybyszewskoga (komad Snijeg, za izvedbu u Zagrebu 1922.) i tekst Moja autobiografija (Hrvatska revija, 1928, 197-204). Nakon smrti pjesnika, autobiografija (nastala 1913.) izašla je u varšavskom tjedniku Wiadomości Literackie (29. IV. 1928.), a Benešić je donosi kao „najautentičniji prikaz i karakteristiku njegovog literarnog lika“ (Benešić, 1928, 197) 14. U knjizi Kritike i članci govori o pojmu „gole duše" Przybyszewskoga i o drami Zlatno runo te tumači zašto taj poljski mistik slabo prolazi među hrvatskim književnicima: „Mi želimo sadržaj, skandal, radnju - a oni daju teorije, kontemplacije i moral - zato nam je Przybyszewski težak, otresamo ga se, jer nam pomućuje naš opći građanski mir i moral“ (Benešić, 1943, 57-62). Za Benešića je Przybyszewski pjesnik simbolist, vođen krilaticom da je ,jedina svrha umjetnosti ljepota, a jedino je boravište ljepote - duša“" (iz djela Na drogach duszy, Benešić, 1943, 59). Duša koja se riješi razuma i osjetila, to je gola duša ${ }^{15}$. Uzmimo u obzir i esej Nacionalizam i patriotizam u književnosti (Narodne novine, 1912), gdje objašnjava što je nacionalizam i ističe da ne presuđuje jezik kojoj književnosti neko djelo pripada nego „sklad s nacionalnim duhom“, koji odlučuje što je domaće, što importirano. Tvrdi, nema svrhe uzdizati djelo koje je samo patriotsko, a ne i umjetničko (jer je ,ppatriotizam“ samo

${ }^{14} \mathrm{U}$ istom podlistku donosi Benešić i feljton $O$ epu Słowackoga „U Švicarskoj “. Na kraju je toga zapisa za našu temu izvanredno važan Benešićev komentar u kojem objašnjava zašto ilirci nisu prevodili Słowackoga (,trebalo je čekati da se javi književna Mlada Poljska potkraj devetnaestog stoljeća, da ga ponovno «otkrije», da ga shvati i proglasi svojim vođom i predšasnikom“; Hrvatska revija, 1928, 208).

${ }^{15}$ Navedimo (u Benešićevu dakle prijevodu) ulomak iz Autobiografije koji pregnantno objašnjava korijenje mladopoljske duševnosti: „Gola duša nije moj originalni izraz; upotrijebio ga je prije mene Adam Mickiewicz u svojim predavanjima o slavenskoj literaturi u Collège de France. Ta sam predavanja, što ih je izdao Wrotnowski u četiri sveska, tada strastveno čitao" (Hrvatska revija, 1928, 202). 
jedna od tendencija u književnosti). Za ideal patriotskoga i umjetničkoga primjer mu je Dušni dan ${ }^{16}$.

Tendencije i stajališta koja, s obzirom na središnje struje hrvatske moderne, možemo prepoznati kao protumoderne ,protu“" su utoliko i što su kod Benešića „importirane“ iz poljske književnosti. Neoromantičnost njegova pjesništva, za koju smo naglasili da je povezana s konzervativnim svjetonazorom, konceptom zavičajnosti, potisnute i pritajene političnosti i potrage za ,skladom s nacionalnim duhom“, podjednako ima veze i sa sponama Mlade Poljske s poljskim romantizmom. Benešić prezire tzv. „nacionalne nehajnike“, osobito takav stav osporava u kazalištu, gdje drži da nema učene publike, pogotovo nema takve koja se „,aklimatizirala hrvatstvu“ (,,jedva čekaju na mig s kompetentnoga i uvaženoga mjesta, da prasnu u smieh nad odlikama našega, hrvatskoga nacionalizma“, Benešić, 1943, 92). Iako ovdje nije riječ o Benešiću književnom povjesničaru, prevoditelju, kulturnom posredniku, antologičaru, uredniku, koji je sav uronjen u hrvatsko-poljski kulturni i društveni kontekst razdoblja međuraća, susret s njegovim opusom sugerira da je posrijedi nekoliko autorskih svijesti, a lirska je ostala potisnuta na račun eruditske, koja je, ipak nadređena, bitno utjecala na narav Benešićeva lirizma. Ta dva poticaja - ugođaj kao temeljna lirska situacija potaknuta nekom senzacijom ili impresijom iz okoline te znakovi iz riznice duhovnopovijesnih znanja - dva su pola Benešićeve poezije. Težnja za ravnotežom između njih obilježuje zbirku u cjelini. Taj drugi pol, izazov književnopovijesnih sklonosti koji je Benešića najdosljednije pratio, doveo nas je do postavke da je Benešić hrvatski pjesnik (i) s poljskom poetikom. Ta differentia specifica, iako suptilna ako se motri samo iz hrvatske vizure, postaje razgovjetnija ako se prisjetimo Mlade Poljske.

\section{Umjesto zaključka - otvaranje novih pitanja}

Kao prvorazredna formalna značajka slobodni stih znak je vremena, odraz težnje epohe kojoj je Benešić pripadao. Ipak, upotreba slobodnoga stiha nije znak njegove pripadnosti bilo kojem književnom pravcu ili struji,

${ }^{16}$ „Za dokaz, kako može patriotička poezija biti liepa, neka dakle posluži primjer iz Mickiewicza“ (Benešić, 1943, 90). 
ali jest simptom epohe. I u kasnoj Benešićevoj zbirci pjesama uočava se poetički kontinuitet: ne odustavši od pjesništva, stihove je pisao 1940. 1941., naslovivši ih Fili, kanconijer ili pjesmarica (44 pjesme, složene kronološki, uokvirene uvodnom i završnom pjesmom, prva je posvećena osobi iz naslova, posljednja čitatelju; objavljeno posmrtno iz ostavštine; Rad JAZU, 1965). S elementima pripovijedanja, na granici pjesničke proze, donosi slične motive - ljubavne, erotske, romantične - s mnogo osjetilnih konkretizacija, kao i u prvoj zbirci. Razlika je u stanovitoj gorčini i autoironiji lirskoga subjekta, koji je u zreloj dobi (u pjesmi Rođendan izrijekom navodi 58 godina), a zaljubljen je u mnogo mlađu osobu (saznajemo i to - povezanu s kazalištem). Promjena se dogodila u metrici: prevladava zatvorena forma, iako ima pjesama u slobodnom stihu (njih šest); iako imaju rimu, stihovi (ima ih kratkih, četveraca, i vrlo dugih, petnaesteraca) ni strofe (katreni) nisu pravilni, a ni rime (kadšto su to asonance i aliteracije). Kao i s prvom zbirkom, i druga je nakon što je objavljena pala u zaborav, opet su je natkrilile druge djelatnosti autora.

Julije Benešić pjesnik je sjetne, rezignirane emocionalnosti u kojoj je lirski subjekt kao zatočen, osuđen na osamu, unutar koje emanira uvjerenje da čistu emociju, ni poetski ni nepoetski, nije moguće intersubjektno prenijeti. Zbog slobodnoga stiha ne može ga se smatrati eksperimentatorom niti inovatorom, nego treba podcrtati da je bio uvjeren da vezani stih ne odgovara motivima o kojima je pisao. Benešić se nadahnjuje na romantičkim izvorima, ali nije to tek utjecanje velikim uzorima nego modernističko preosmišljavanje kojemu je cilj svojevrsna obnova romantičkoga mišljenja. Jasno, ne piše Benešić onako kako su pisali pjesnici romantičke epohe, piše onako kako se pisalo na prijelazu stoljeća - potreba da stilizira i konceptualizira i slobodni stih izrazito je esteticistička. Benešić je sve to - impresionist, esteticist, neoromantik, politički konzervativac i formalni modernist, kakvim se ukazuje čim ga se rastereti apriorne usporedbe s hrvatskim suvremenicima (pogotovo s drugim pjesnicima slobodnog stiha iz tog doba) i kulturnopovijesno situira u inonacionalni, izrijekom poljski, kulturni kontekst na prijelazu stoljeća. Navest ćemo značajke bez kojih obuhvatnija prosudba ne bi bila moguća: odabir slobodnoga stiha ne znači da pjesnik nije mario za tradicionalnu formu ili da je bio nevješt u vezanom stihu; mjestimična upotreba kolokvijalnoga jezika sigurno nije odraz jezične nebrige; sjećanje kao temeljna lirska situacija nije samo znak 
uronjenosti u prošlost nego odraz potrebe da subjekt u sadašnjosti uočava znakove iz svoje prošlosti. Budući da to čini ponajviše osjetilno (asocijacijama koje pobuđuju boje, zvukovi, mirisi), pri čemu dojmovi iz sadašnjosti potiču sjećanje na prošlost, posrijedi je impresionistički intimizam (Žmegač, 1997, 73-80) ${ }^{17}$.

Zbirka započinje svojevrsnim credom:

Istrgnuti ste iz dnevnika, koji je bio pisan samo u ljubavi i jačoj još mržnji, u samoći; istrgnuti ste, a iza vas ostade još rpa papira ispisana zgrčenim slovima triumfa i očaja. Kakvu imate vrijednost za druge, ne hajem - za mene ste imali cijenu najmilijih uspomena. Sada ste mi tudji i daleki kao što je dalek trag, što ga je ostavila Zemlja onih dana i onih noći.

Otud tumačenja zbirke kao dnevničkoga djela i isticanje prisjećanja i samoanalize kao subjektove tipične situacije. Završimo pjesmom Mome$n a t^{18}$, kao primjerom impresionističke mimeze kakvom se pjesnik služio:

Ti me gledaš. Takav pogled

Nikad nisam podnosio, nikad nisam

Takav pogled duše čovječanske gledo.

Ti me gledaš. Ja sam upro pogled tvrdi:

Sad da vidim, tko će prvi da popusti.

U tvom oku drhće smiješak, lahor vidim

Kako maše tvojom kosom, usne vidim

Kako drhću u čeznuću, znatiželji.

Ti me gledaš. Ja sam upro pogled muški,

I da vidim, tko će prvi da popusti.

Tvoje oko zatitralo.

Tvoju dušu držim laku, gledam u nju,

Sletjela mi na dlan, sitna, pa je motrim

Kao oko pepeljasto, dušo, tvoje.

Duša tvoja, ptica mala, nešto strepi,

drhturi i boji me se.

Zar te ispred moje duše strah spopada?

Ne boj me se, ptico mala!

Pusti krila, ne lepršaj,

ne otidji, ne odleti, dušo moja!

${ }^{17}$ Sintagma se odnosi na jednu od pojavnosti poetskoga impresionizma u zreloj fazi.

${ }^{18}$ Služimo se prvim izdanjem (Benešić, 1922, 50). Ispod pjesme piše da je nastala u Pragu, 1. VII. 1906. 


\section{Izvori}

Benešić, J. (1917). O hrvatskom ritmu, „Savremenik“ br. 12, str. 35-39.

Benešić, J. (1922). Istrgnuti listovi. Zagreb: Tisak i naklada knjižare Kugli.

Benešić, J. (1934). Dwa odczyty o Polakach i o sobie. Warszawa: Drukarnia Podstołeczna, str. 5-22.

Benešić, J. (1943). Kritike i članci. Zagreb: Izdanje Hrvatskog izdavalačkog bibliografskog zavoda.

Benešić, J. (1981). Iza zastora. Osam godina u Varšavi. „Rad JAZU“, knj. 390. Zagreb: Jugoslavenska Akademija znanosti i umjetnosti, str. 245-633.

Današnja Poljska. Zbornik Društva za kulturnu suradnju Hrvatske s Poljskom. (1948). Zagreb: Tipografija.

Przybyszewski, S. (1928). Moja autobiografija. Prev. J. Benešić. „Hrvatska revija“ br. 1, str. 197-204.

\section{Literatura}

Barac, A. (1947). Veličina malenih. Zagreb: Nakladni zavod Hrvatske.

Batušić, N., Kravar, Z., Žmegač, V. (2001). Književni protusvjetovi. Zagreb: Matica hrvatska.

Bloom, H. (1994). The western canon. New York -San Diego - London: Harcourt Brace \& Company.

Brzozowski, S. (1910). Legenda Młodej Polski. Studja o strukturze duszy kulturalnej. Lwów: Nakładem Księgarni Polskiej B. Połonickiego.

Jurić, S. (2003). Tendencije u ranom hrvatskom slobodnom stihu. „Umjetnost riječi“ br. 1-2, str. 107-128.

Jurić, S. (2005). Slobodni stih u eksplicitnim poetikama. „Književna smotra“ br. $136 / 137(2 / 3)$, str. 3-30.

Kravar, Z. (2001). Suvremene teme i konzervativni nazori u lirici A. G. Matoša. U: N. Batušić, Z. Kravar, V. Žmegač, Književni protusvjetovi. Zagreb: Matica hrvatska, str. 89-96.

Kravar, Z. (2003). Antimodernizam. Zagreb: AGM.

Kravar, Z. (2005). Znaci vremena u hrvatskoj književnosti 1920-1930. U: Svjetonazorski separei. Zagreb: Golden marketing-Tehnička knjiga, str. 81-98.

Pavličić, P. (2003). Julije Benešić kao pjesnik. U: Barokni pakao. Zagreb: Naklada Pavičić, str. 297-300.

Pejaković, H. (1994). Julije Benešić (1883.-1957.). U: Julije Benešić, Izabrani tekstovi. Vinkovci: Slavonska naklada Privlačica, str. 137-49.

Žmegač, V. (1997). Duh impresionizma i secesije. Zagreb: Zavod za znanost o književnost Filozofskoga fakulteta u Zagrebu. 